\title{
Fire Simulation in House Conditions
}

\author{
RADOJE B. JEVTIĆ, School of Electrical Engineering "Nikola Tesla", Niš
}

\author{
Review paper \\ UDC: $614.841 .41: 519.876 .5$ \\ DOI: 10.5937/tehnika1601160J
}

\begin{abstract}
Fire simulation presents very powerful, economic and safe way for determination of potential fire scenarious in particular object.Because the fire presents very unpredictable event, it is very important to , as much is possible, predict its potential spreading through some object.Residential objects, such as houses, barracs, buildings and similar present the special objects according to fire becouse they could contain a grat number of people inside. This paper has written to show the possible fire spreading in house conditions based on simulation in PyroSim software.
\end{abstract}

Key words: fire, simulation, house

\section{INTRODUCTION}

Fire presents great danger for human lives and material properties. Through history, fires made great material damage and took many lives. Because of that fact, the fire protection is probably old as much as the discovery of the fire. This discipline has developed through the history according to the science and technical development of the human society. The basic techniques for fire protection and stopping the fire propagation were consisted to the removing of the fire material, reducing and bypassing of heat and reducing of oxygen concentration in order to slow or stop the chain of the chemical reaction during the fire process. Through the history, the regulation of fire protection followed, in the most cases, the development of the science and technology. For example, the oldest document about law regulation of fire protection, also the first document about fire protection in history generally, was Hammurabi ‘s law (18 century B.C.).The first fire organize units were noted during the rule of Augustus Caesar, known as Octavian (63 year B.C.). Notable fire protection in Europe, generally, was recorded from 1100 to 1600, especially in England and Russia. In America, for example, the first law regulation about fire protection showed in 1661, after huge fire in Boston. Further advancement of fire protection till today was fallowed with many new discoveries in

Author's address: Radoje Jevtić, School of Electrical Engineering "Nikola Tesla", Niš, Aleksandra Medvedeva 18

Paper received: 27.10.2015.

Paper accepted: 15.12.2015. science and technology, such as electrical fire signalization, automation fire, smoke, heat and flame detectors, central fire detection units etc.

Nowadays level of fire protection implies the projection of complete fire system based on valued standards. It is very complex process, because, beside many start bases of projection which were predicted by law standards, regulation and references, it includes many factors which were attained according to the fire risk analyze, characteristics of the object construction, characteristics of the activities and production process in object, materials and stuff in object, working and professional characteristic of personnel, etc. That implies very complex process of definition of the elementary problems, which is necessary to be done before the process of the fire system projection itself. It can be concluded that the one of the most important problem in the fire systems projection is the potential fire propagation. The fire propagation could be distinguished through three stages: the fire development stage (development from ignition to the "flashover"), the fully developed fire stage and the calming fire stage. Very complex and danger fire spreading could be in residential objects and houses, where the presence of humans presents imminence. The example of fire spreading in house is presented on figure 1 .

It can be concluded that the one of the most important problem in the fire systems projection is the potential fire propagation. The fire propagation could be distinguished through three stages: the fire development stage (development from ignition to the "flashover"), the fully developed fire stage and the calming fire stage. According to all exposed facts, it can be 
concluded that the fire is very complex case and that it is necessary to know all of its aspects in order to protect human lives and material properties.

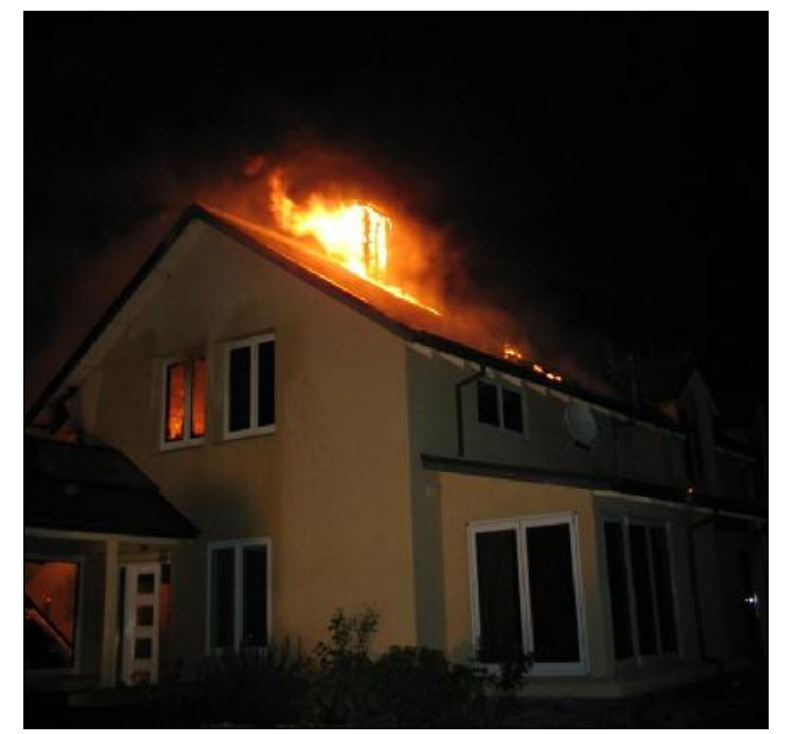

Figure 1 - An example of fire spreading in house

There were several ways for eventual fire prediction according to lot of starting factors and conditions. One of the most successful, the most economical and the safest ways for potential fire prediction is usage of the simulation software such as PyroSim 2012 [1,2].

\section{SIMULATION SOFTWARE AND SIMULATION MODEL}

PyroSim is a graphical user interface for the Fire Dynamics Simulator (FDS). FDS models can predict smoke, temperature, carbon monoxide, and other substances during fires. The results of these simulations have been used to ensure the safety of buildings before construction, evaluate safety options of existing buildings, reconstruct fires for post-accident investigation, and assist in firefighter training. FDS is a powerful fire simulator which was developed at the National Institute of Standards and Technology.

FDS simulates fire scenarios using computational fluid dynamics (CFD) optimized for low-speed, thermally-driven flow. This approach is very flexible and can be applied to fires ranging from stove-tops to oil storage tanks. It can also model situations that do not include a fire, such as ventilation in buildings. FDS and the Smokeview visualization program are both closely integrated into PyroSim. The PyroSim interface provides immediate input feedback and ensures the correct format for the FDS input file. It can be worked in either metric or English units and it can be switched between the two at any time. In addition, PyroSim offers high-level 2D and 3D geometry creation features, such as diagonal walls, background images for sketching, object grouping, flexible display options, as well as copying and replication of obstructions (0). DXF files that include either 3D faces or 2D lines that can be extruded to create 3D objects in PyroSim, could be imported [3].

The house used as simulation example for fire spreading, smoke and heat propagation has dimensions of $10 \mathrm{~m} \mathrm{x} 9 \mathrm{~m} \times 5,2 \mathrm{~m}$. The house has two floors with rooms, both with height of 2,6 $\mathrm{m}$. At the ground floor, there are living room, kitchen, garage and pantry. There are also doors, stairs and windows. At the first floor, there are five bedrooms. The rooms are arranged with objects typical for house. The presentation of objects, theirs numbers and dimensions used in simulation are presented in table 1, while the simulation models of a house in PyroSim 2012 (front and top view) are presented on figures 2 and 3.

Table 1. The presentation of objects, theirs number and dimensions used in simulation

\begin{tabular}{|c|c|c|}
\hline Object & Number of objects & Dimensions \\
\hline Bed & 5 & $1,4 \mathrm{~m} \times 2 \mathrm{~m}$ \\
\hline Chair & 6 & $40 \mathrm{~cm} \mathrm{x} 40 \mathrm{~cm} \mathrm{x} 45 \mathrm{~cm}$ \\
\hline $\begin{array}{l}\text { Wooden } \\
\text { desk }\end{array}$ & 1 & $138 \mathrm{~cm} \mathrm{x} 84 \mathrm{~cm}$ \\
\hline Dresser & 6 & $50 \mathrm{~cm} \times 80 \mathrm{~cm} \times 2,2 \mathrm{~m}$ \\
\hline $\begin{array}{l}\text { Cabinet } \\
\text { lower }\end{array}$ & 6 & $70 \mathrm{~cm} \mathrm{x} 40 \mathrm{~cm} \mathrm{x} 50 \mathrm{~cm}$ \\
\hline $\begin{array}{l}\text { Cabinet } \\
\text { upper }\end{array}$ & 4 & $70 \mathrm{~cm} \times 40 \mathrm{~cm} \mathrm{x} 50 \mathrm{~cm}$ \\
\hline Seat short & 6 & $50 \mathrm{~cm} \times 50 \mathrm{~cm} \times 90 \mathrm{~cm}$ \\
\hline Seat long & 2 & $2 \mathrm{~m} \times 60 \mathrm{~cm} \times 90 \mathrm{~cm}$ \\
\hline
\end{tabular}

The materials that were used are: gypsum, concrete, upholstery, plywood, pine wood, oak wood, card board, aluminum, iron, steel, plastic and glass. All of these noted materials have theirs own properties important for correct simulation (density, specific heat, conductivity ...) $[4,5]$.

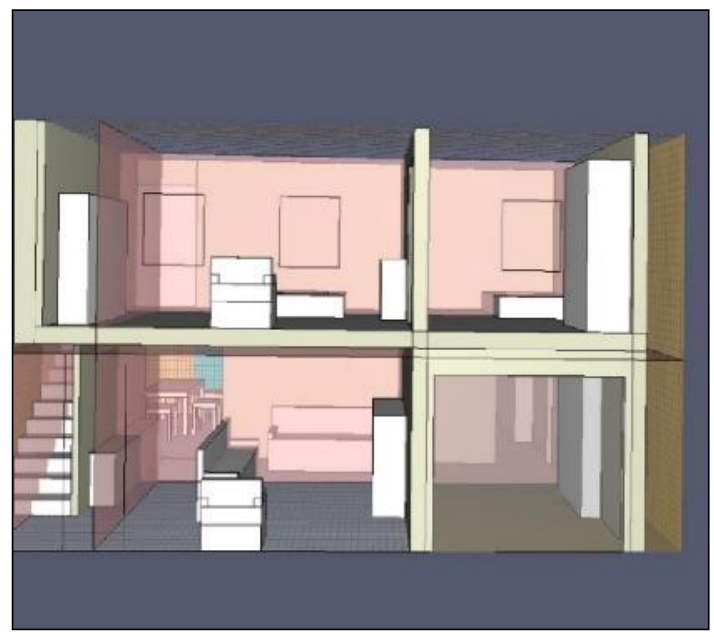

Figure 2 - The simulation model of house (front view) in PyroSim 2012 


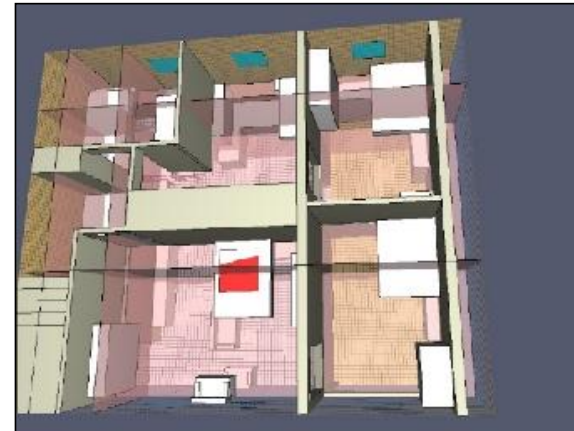

Figure 3 - The simulation model of house (top view) in PyroSim 2012

\section{SIMULATION}

The simulation of the fire was realized for three different scenarios: the first scenario implied that the fire source was in the bedroom on the fire second scenario implied that the fire source was in the kitchen at the ground floor and the third scenario implied that the fire source was in the garage at the ground floor. The size of fire source was $85 \mathrm{~cm}$ x $85 \mathrm{~cm}$ with its HRR (Heat Release Rate per area) of $500 \mathrm{~kW} / \mathrm{m}^{2}$. The simulation time duration, for all of three scenarios, was 500 seconds. The development of smoke and flame and thermal presentations of realized simulations for all of three scenarios are presented on figures from 4 to 12 .

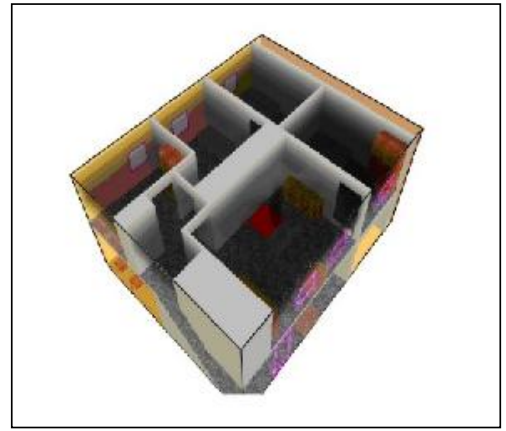

Figure 4 - An example of house simulation in PyroSim 2012 for the first scenario after 380 secondssmoke presentation

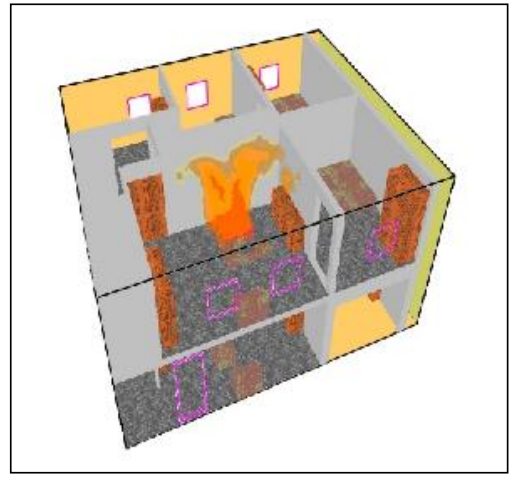

Figure 5 - An example of the house simulation in PyroSim 2012 for the first scenario after 380 seconds-flame presentation

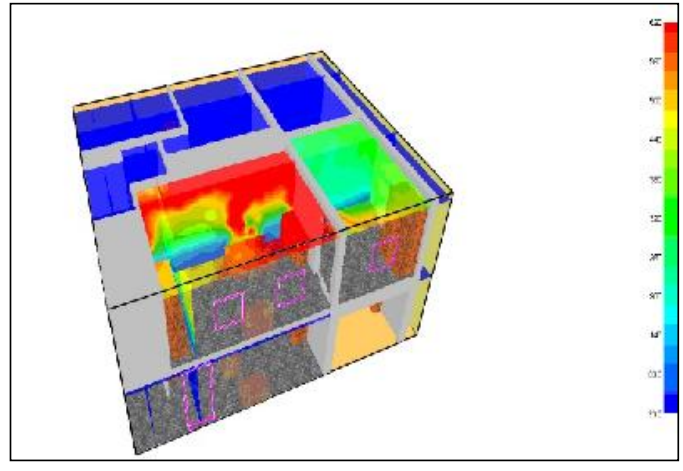

Figure 6 - An example of the house simulation in PyroSim 2012 for the first scenario after 100 seconds- thermal presentation

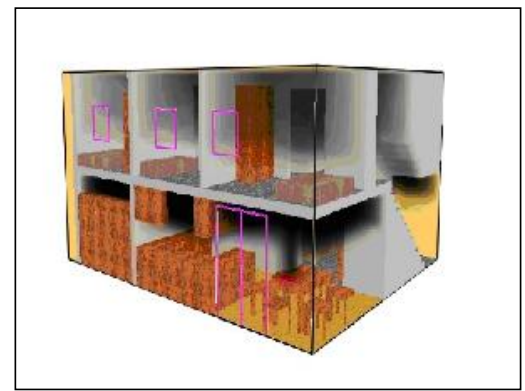

Figure 7 - An example of the simulation model of house in PyroSim 2012 for the second scenario after 289 seconds-smoke presentation

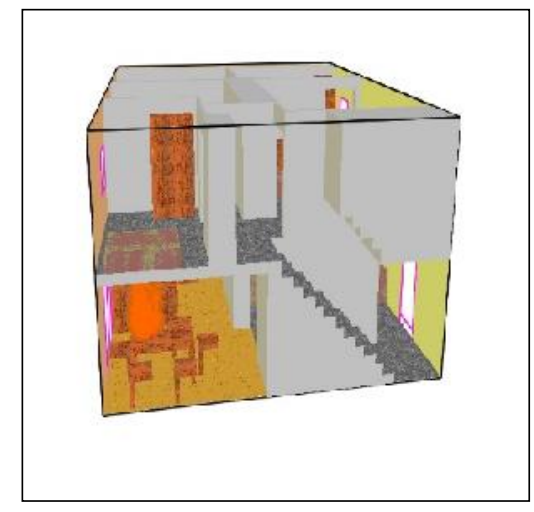

Figure 8 - An example of the house simulation in PyroSim 2012 for the second scenario after 127 seconds-flame presentation

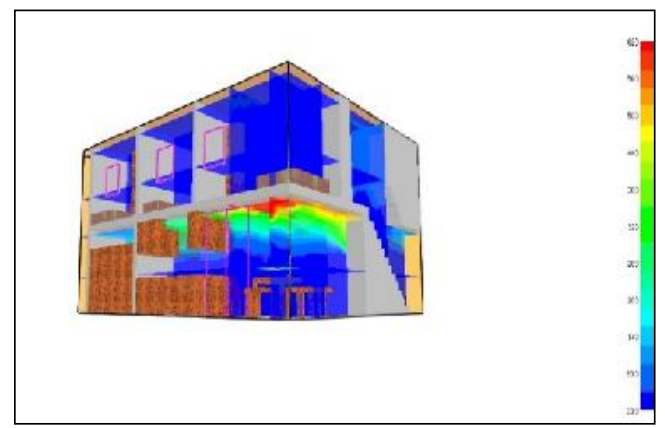

Figure 9 - An example of the house simulation in PyroSim 2012 for the second scenario after 180 seconds- thermal presentation 


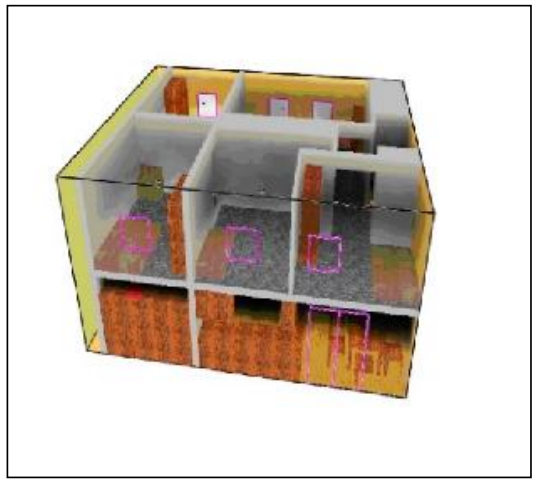

Figure 10 - An example of the simulation model of house in PyroSim 2012 for the third scenario after 247 seconds-smoke presentation

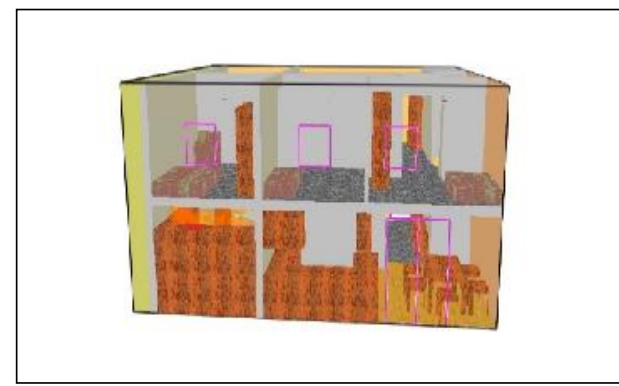

Figure 11 - An example of the house simulation in PyroSim 2012 for the third scenario after 84 seconds-flame presentation

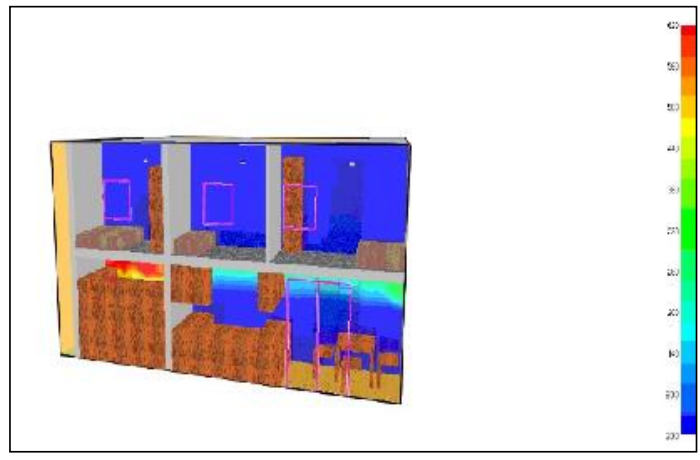

Figure 12 - An example of the house simulation in PyroSim 2012 for the third scenario after 169 seconds- thermal presentation

\section{SIMULATION RESULTS ANALYSE}

Simulations lasted 83 hours for the first scenario, 87 hours for the second scenario and 89 hours for third scenario. The machine used for simulations was Siemens Esprimo Mobile V5535 with Intel(R) Celeron(R) M CPU 530 processor at $1.73 \mathrm{MHz}$ and 4 GB RAM memory. The complete simulations results occupied $1,95 \mathrm{~GB}$ of disk space.

The realized results, especially related to the temperature and smoke distribution, were generally expected. The temperature rises were over $74{ }^{\circ} \mathrm{C}$ (this is the alarm activation temperature for the most of the heat detectors in order to avoid false alarms, although the limit value of temperature that should be detected is 57 ${ }^{\circ} \mathrm{C}$ according to the EN 54 and NFPA 72) after just several seconds, in all of three cases, which was expected according to the facts of size and HRR of fire source [6]. Related to some other possible scenarios (for example fire at start or smoldering fire at early stage) noted scenarios implied fire in burning phase [7]. The presentation of the temperatures rise is presented on figure 13.

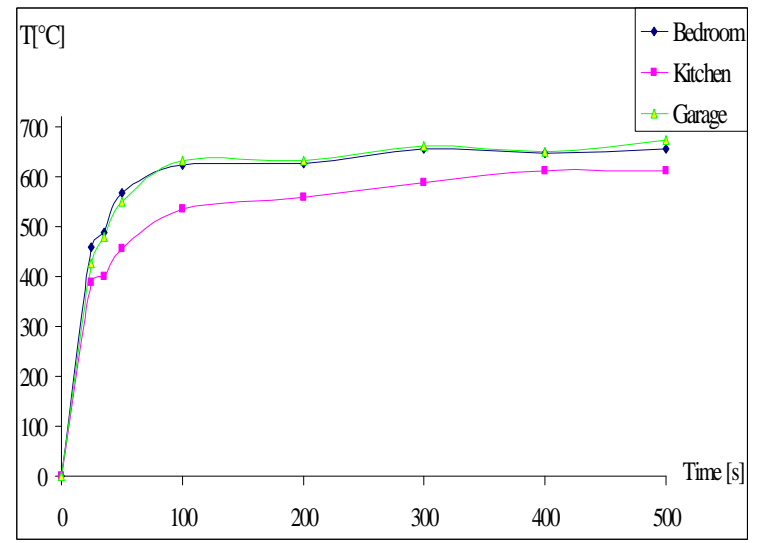

Figure 13 - The temperatures rise for all of three scenarios

The heat from the fire sources in all of three cases transfers to the other objects in the rooms and on the walls. The presumption was that all of windows were closed. An example of walls temperatures is presented on figure 14. At the same example, the arrangement of the heat sensors is presented.

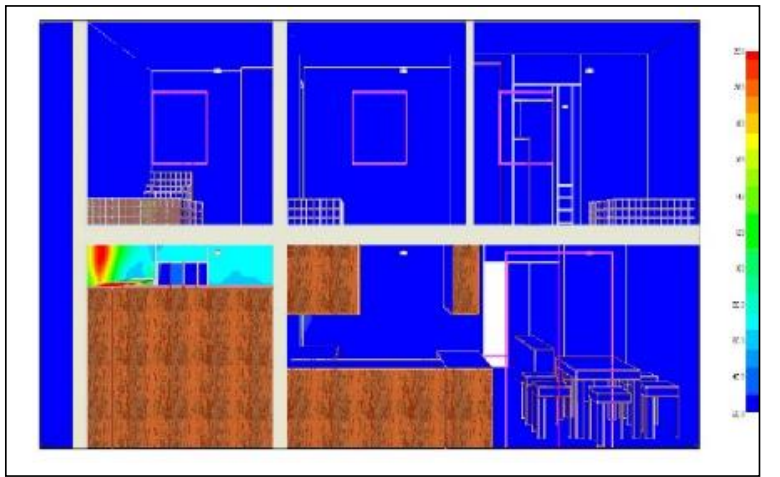

Figure 14 - PyroSim 2012 simulation presentation of walls temperatures after 57 seconds from the fire start

The smoke from the fire sources in all of three cases also transfers to the other rooms in object, what is very important for smoke detection and arrangement of smoke detectors. For fire source in the bedroom at the first floor, the complete quantity of smoke will concentrate on the first floor and smoke sensors on the ground floor will not activate for the time determined by simulation. For fire sources in the garage and in the kitchen, the reaction time difference between the nearest and the farthest sensors could be several tens of 
seconds. The nearest sensor implied sensor in the garage and in the kitchen, for the third and for the second fire scenario, and the farthest sensor implied sensor in bedroom 2 on the first floor, above the garage. The simulation results for smoke sensors when the fire source was in the garage and the farthest smoke sensor was in the bedroom 2 above garage are presented on figures 15 and 16, while the simulation results for smoke sensors when the fire source was in the kitchen and the farthest smoke sensor was in the bedroom 2 above garage are presented on figures 17 and 18.

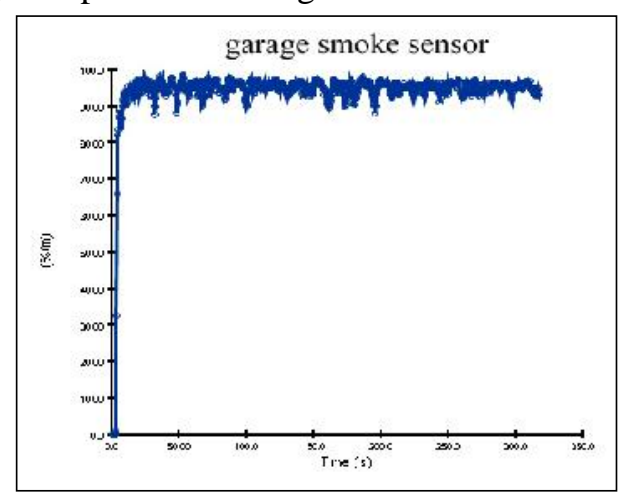

Figure 15 - Simulation results of garage smoke sensor for the third fire simulation scenario

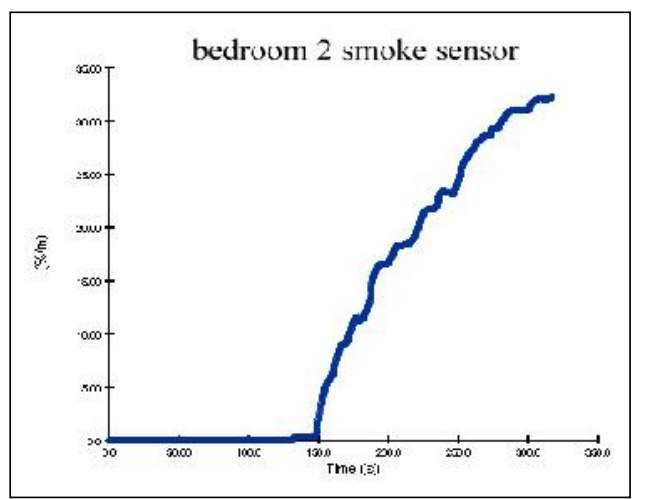

Figure 16 - Simulation results of bedroom above garage smoke sensor for the third fire simulation scenario

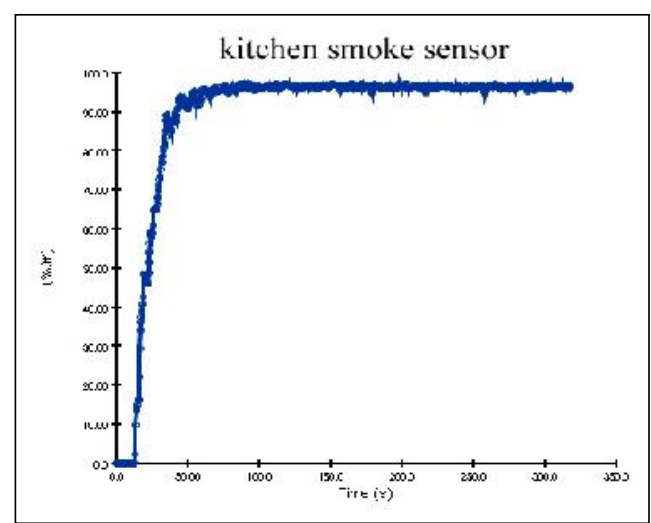

Figure 17 - Simulation results of kitchen smoke sensor for the second fire simulation scenario

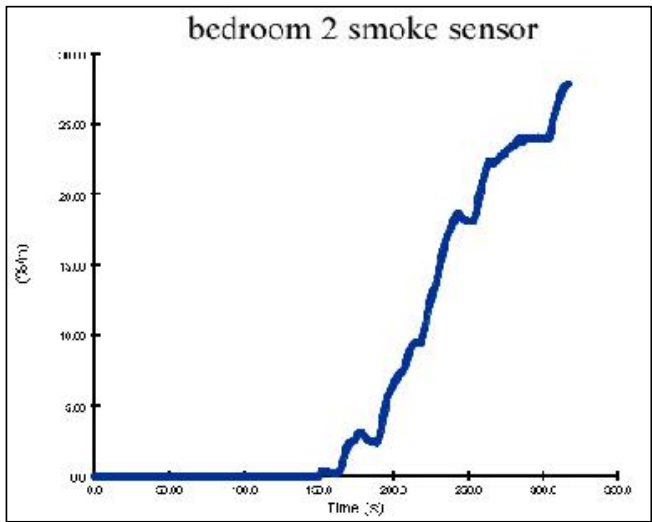

Figure 18 - Simulation results of bedroom above garage smoke sensor for the second fire simulation scenario

\section{CONCLUSION}

Prediction of fire and its potential spreading is very important and complex task for every object including houses and residential objects. The detection of fire at early stage is very important; but also the detection in other fire phases, such as burning phase or heat development phase, otherwise fire can cause much damage and endanger human lives or destructs material properties. Simulation of fire spreading could show the potential fire spreading for different objects and different scenarios of fire sources power. The simulation of fire spreading and prediction of possible fire scenarios are very important for determination of potential evacuation scenarios. According to the fact those houses and other residential objects could have lot of humans inside, the proper, fast and safe scenario for evacuation presents one of the main tasks in human lives protection. The simulation of some particular object enabling determination of different parameters, for example, temperature rate, heat released rate, smoke rate and similar. Simulation results showed that heat and smoke detectors were good positioned. Simulation results for every simulated object could show the optimal positions for fire detectors, smoke detectors, carbon monoxide detectors, flame detectors and other fire installations in order to safe human lives, material properties and stopping of fire. These results also can show the fastest evacuation routes for human evacuating or fire stairs upgrading [8-10]. As an example, the evacuation of 5,10 and 15 occupants randomly positioned, was realized. House simulation model used in this paper, in PyroSim 2012, was transferred to PathFinder 2012 simulation software and evacuation was realized. The speeds of occupants were $1,5 \mathrm{~m} / \mathrm{s}, 2,5 \mathrm{~m} / \mathrm{s}$ and $3,5 \mathrm{~m} / \mathrm{s}$. An evacuation moment for an example with 15 occupants randomly positioned is presented on figure 19. The results of evacuation times were presented on figure 20 . 


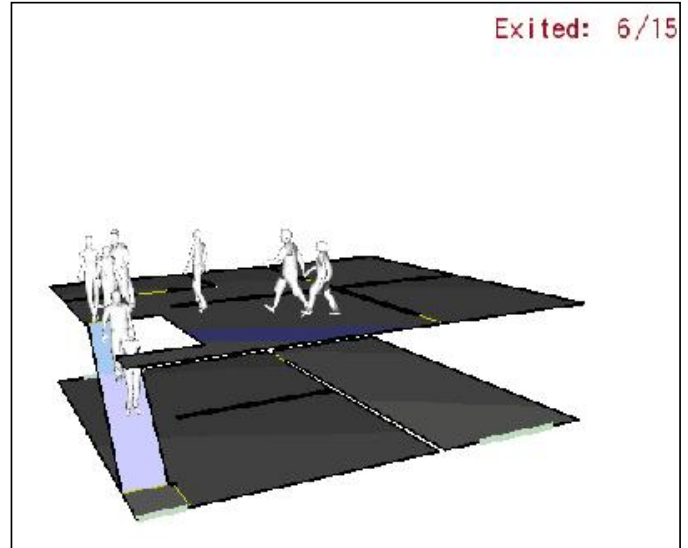

Figure 19 - An evacuation moment for an example with 15 occupants randomly positioned in Pathfinder 2012 presentation

In the objects with lot of humans inside it, during the fire time, many unexpected scenes could be done. For example, one these this events is panic. Evacuation results for 15 occupants with $3,5 \mathrm{~m} / \mathrm{s}$ could be a proper evidence for that kind of situation-panic causes jamming and increases time for evacuation. Taking into account the fact that the fire could case a lot of smoke with carbon monoxide, which could be much faster binds for hemoglobin other the oxygen (several hundreds times faster), together with panic and stress behavior, could cause tragic consequences $[11,12]$. The results of evacuation times were presented on figure 20.

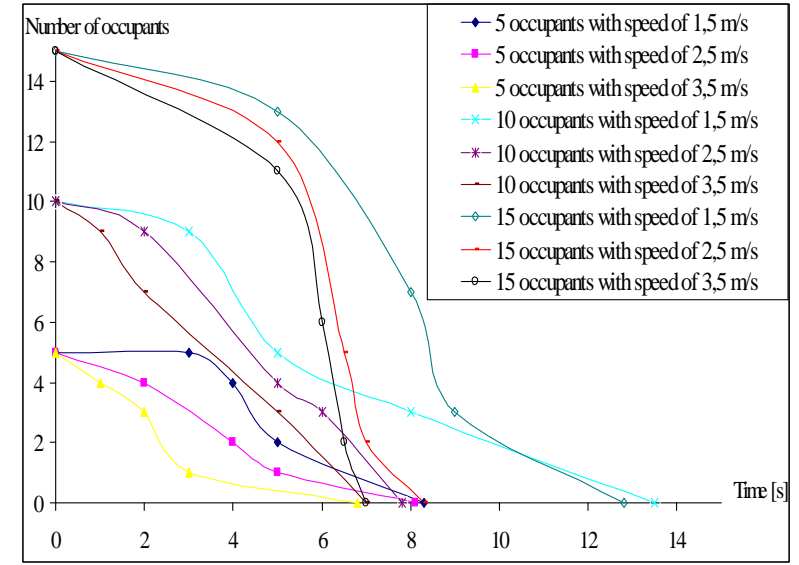

Figure 20 - House evacuation results for 5, 10 and 15 occupants with speeds of $1,5 \mathrm{~m} / \mathrm{s}, 2,5 \mathrm{~m} / \mathrm{s}$ and $3,5 \mathrm{~m} / \mathrm{s}$

Presented results showed the great importance of simulation software in fire prediction, potential fire spreading, potential arrangement of fire detectors, planning and determination of primary and secondary evacuation routes, etc. Fire in real conditions presents very unpredictable and hard to control occurrence, so, possibilities to predict fire behavior in virtual conditions could significantly decrease its real potential influence and damage on human lives and material properties.

\section{REFERENCES}

[1] Blagojević, M., Alarm systems, Faculty of occupational safety, Niš, 2011.

[2] Jevtić B. R, The importance of fire simulation in fire prediction, Tehnika, Vol 1, pp. 153-158, ISSN 00402176, Beograd, 2014.

[3] PyroSim user manual, Thunderhead engineering, 2012.

[4] Group of authors, Chemistry and technology handbook, Publicher working organisation Rad, Belgrade, 1987.

[5] Radošević N, Chemists and technologist handbook, Technical book, Belgrade, 1968.

[6] NFPA 72, National Fire Alarm Code, 1999 Edition, NFPA, 1999.

[7] Jevtić B. R, Heat detectors-Division, Positioning in Object and Simulation, Tehnika, Vol 2, pp. 303-311, ISSN 0040-2176, Beograd, 2015.

[8] Jevtić B. R, Blagojević Đ. M, Simulation of the school object evacuation, Tehnika, Vol 2, pp. 365-370, Belgrade, 2013.

[9] Jevtić B. R, Ničković T. J, Simulation of residential object evacuation, 57 ${ }^{\text {th }}$ ETRAN CONFERENCE, Zlatibor, 2013.

[10]Jevtić B. R, Simulation of the shopping centre Zona I evacuation, TECHNICS-special edition, pp. 121125, ISSN 0040-2176, Beograd, 2014.

[11]Jevtić B. R, The influence of fire consequencies on humans health and its possible elimination, Zdravstvena zaštita, Vol 3, pp. 53-59, YU ISSN 030503208, Beograd, 2014.

[12]Jevtić B. R, Combustion as fire consequence-great danger for humans health, Zdravstvena zaštita, Vol 6., pp. 55-62, YU ISSN 03050-3208, Beograd, 2015. 


\section{SUMMARY}

\section{SIMULACIJA POŽARA U KUĆNIM USLOVIMA}

Simulacija požara predstavlja veoma moćan, ekonomičan i siguran način za određivanje potencijalnih scenarija požara u određenom objektu. Zato što požar predstavlja veoma nepredvidiv događaj, veoma je važno da se, koliko god je to moguće, predvidi njegovo potencijalno širenje kroz neki objekat.Objekti za stanovanje, kao što su kuće, barake, zgrade i slično predstavljaju posebne objekte u odnosu na požar zato što mogu sadržati veliki broj ljudi unutar sebe. Ovaj rad je napisan da pokaže potencijalno širenje požara u kućnim uslovima koje je zasnovano na simulaciji u programu PyroSim.

Ključne reči: požar, simulacija, kuća 